\title{
UPAYA MENINGKATKAN KEMAMPUAN KONEKSI MELALUI PENDEKATAN CONTEXTUAL PADA MATERI SISTEM PERSAMAAN LINIER DUA VARIABEL DI KELAS 8C SMP NEGERI I MALEBER
}

\author{
Ayi Haryati, S.Pd \\ SMP Negeri 1 Maleber \\ ayiharyati@yahoo.com
}

\begin{abstract}
The purpose of this classroom action research: 1) To obtain the aplication of contextual approach in learning mathematics to improve mathematical connection ability on equations system liniear two variable; 2) to determine attitudes and opinions of students towards mathematics learning that uses contextual approach. The research was conducted in class VII C SMP Negeri 1 Maleber in the school yaer $2015 / 2016$ the number of subject is 30 students through three cycles with completeness minimal criteria (CMC) 74 . The result in cycle 1 , the number of students who achieve mastery of at least 12 students (40\%) and unsuccsessful 18 students $(60 \%)$. It means that classical completemenss yet achieved only an average value of 68. In the cycle II students who achieve mastery of at least 18 students $(60 \%)$ and unseuccsessful 12 students $(40 \%)$, it means there is an increase in classical completeness as much as $20 \%$ compare with the cycle I. In the cycle III students achieve mastery of at least 23 students (76,67\%), and which has not been achieved 7 students $(13,33 \%)$. It means that there is an increase of 36,67 from the cycle I and 16,67 from the cycle II. Based on the students questionnaire response was obtained by $25(83,34 \%)$ students obtained a sense of fun and the responses of 20 $(67 \%)$ students said that easy to understand. So contextual approach can improve the students mathematic connection ability in class VIIIC SMP Negeri 1 Maleber on equations system liniear two variable.
\end{abstract}

Keyword: Mathematic Connection Ability, Contextual Approach, Equations System Liniear Two Variable

\section{Abstrak}

Penelitian tindakan kelas ini bertujuan 1) memperoleh gambaran penerapan pendekatan contextual dalam pembelajaran matematika untuk meningkatkan kemampuan koneksi matematis pada materi sistem persamaan linear dua vaariabel; 2) mengetahui sikap serta pendapat siswa terhadap pembelajaran matematika yang menggunakan pendekatan contextual. Penelitian ini dilaksanakan di kelas VIII C SMP Negeri 1 Maleber Tahun Pelajaran 2015/2016 dengan jumlah siswa 30 melalui tiga siklus dengan kriteria ketuntasan minimal (KKM) 74. Hasil Pada siklus 1, jumlah siswa yang mencapai ketuntasan minimal 12 siswa (40 \%) dan yang belum berhasil 18 siswa (60\%). Ini berarti ketuntasan klasikal belum tercapai hanya rata rata nilai 68. Pada siklus II siswa yang mencapai ketuntasan minimal 18 siswa 
(60\%), dan yang belum berhasil 12 siswa (40\%). Ini berarti ada peningkatan ketuntasan klasikal sebanyak $20 \%$ dibanding dengan siklus I. Sedangkan pada siklus III siswa yang mencapai ketuntasan minimal 23 siswa $(76,67 \%)$, dan yang belum tercapai 7 siswa (13,33 \%). Ini berarti ada kenaikan 36,67 \% dari siklus I dan 16,67\% dari siklus II. Berdasarkan angket siswa diperoleh respon sebanyak 25 siswa $(83,34$ $\%)$ menyatakan rasa senang serta didapat respon 20 siswa (67\%) menyatakan mudah memahami. Jadi pendekatan Contextual dapat meningkatkan kemampuan koneksi matematis siswa di kelas VIIIC SMP Negeri 1 Maleber pada materi sistem persamaan linear dua variabel.

Kata Kunci : Kemampuan Koneksi Matematis, Pendekatan Contextual, Sistem Persamaan Linear Dua Variabel.

\section{PENDAHULUAN}

Berdasaran kurikulum satuan pendidikan (KTSP) SMPN 1 Maleber Tahun 2006, pada mata pelajaran matematika, salah satunya siswa diharapkan mampu membuat hubungan antara dunia nyata dalam kehidupam sehari hari dengan materi yang sedang dipelajari. Pembelajaran seperti itu dikenal dengan nama pendekatan contextual .

Berpegang dari hasil belajar pada materi sebelumnya yakni pada materi Sistem Persamaan Linear dua variabel (SPLDV) dengan menggunakan metode grafik diperoleh hasil yang kurang memuaskan. Dilihat dari ketuntasannya diperoleh data siswa yang tuntas 10 siswa dari 30 siswa. $(33,3 \%)$. dengan kata lain lebih dari $50 \%$ siswa belum mencapai ketuntasan belajar. ini berarti kemampuan siswa dalam materi SPLDV di indikasikan ketidakmampuan dalam menghubungkan materi dalam kehidupan sehari-hari.

Dalam pembelajaran matematika ketidakmampuan siswa dalam menghubungkan materi dalam kehidupan sehari-hari merupakan permasalahan dalam kemampuan koneksi matematis. Kemampuan koneksi matematis merupakan kemampuan sangat penting karena akan membantu penguasaan pemahaman konsep yang bermakna dan membantu menyelesaikan tugas pemecahan masalah tidak hanya keterkaitan konsep dengan kehidupan nyata tetapi juga melalui keterkaitan antara konsep matematika dan antara konsep matematika dengan konsep dalam disiplin lain. Hal ini sejalan dengan pendapat Sumarmo (2012) yang menyatakan bahwa, kemampuan koneksi matematika ini akan membantu siswa dalam menyusun model matematika yang juga menggambarkan keterkaitan antar konsep dan atau data suatu masalah atau situasi yang diberikan.

Untuk mengatasi masalah tersebut, khususnya masalah rendahnya kemampuan koneksi matematis siswa dalam materi SPDLV maka perlu diupayakan model pembelajaran yang tepat. Salah satuya adalah pembelajaran dengan pendekatan Contextual. Pendekatan kontekstual adalah suatu konsep atau pendekatan belajar dan mengajar dengan situasi dunia nyata dan motivasi siswa untuk berbuat koneksi antara pengetahuan dan aplikasinya dengan kehidupan mereka sebagai anggota masyarakat. Pembelajaran kontekstual secara umum memiliki dua peranan dalam pendidikan yaitu sebagai filosofi pendidikan dan sebagai rangkaian kesatuan dari 
strategi pendidikan. Sebagai filosofi pendidikan, pembelajaran kontekstual mengasumsikan bahwa peranan pendidikan adalah membantu peserta didik menemukan makna dalam pendidikan dengan cara membuat hubungan antara apa yang mereka pelajari di sekolah dan cara-cara menerapkan pengetahuan tersebut di dunia nyata. Sedangkan sebagai rangkaian kesatuan dari strategi pendidikan, pembelajaran dengan kontekstual memadukan tehnik-tehnik yang membantu peserta didik sebagai pembelajaran dan reflektif terhadap pengalamannya.

Menurut Sanjaya (2006)

Contextual Teaching and Learning (CTL) adalah suatu strategi pembelajaran yang menekankan kepada proses keterlibatan siswa secara penuh untuk dapat menemukan materi yang dipelajari dan menghubungkannya dengan situasi kehidupan nyata sehingga mendorong siswa untuk dapat menerapkannya dalam kehidupan mereka. Berdasarkan pemaparan di atas maka kemampuan koneksi matematis siswa dalam materi SPLDV diharapkan dapat meningkat melalui pembelajaran Contextual.

Penelitian ini bertujuan untuk 1) memperoleh gambaran apakah dengan diterapkannya pendekatan constextual dalam pembelajaran matematika dapat meningkatkan kemampuan koneksi matematika siswa, 2) mengetahui aktifitas siswa selama pembelajaran berlangsung. 3) mengetahui sikap dan pendapat siswa terhadap pembelajaran matematika yang menggunakan pendekatan constextual.

KAJIAN PUSTAKA

Pembelajaran Contextual

Menurut Johnson (2007)

Contextual teaching and Leraning

(CTL) adalah suatu sistem belajar yang didasarkan pada filosofi bahwa seorang pelajar akan mau dan mampu menyerap materi pelajaran jika mereka dapat menangkap makna dari pelajaran tersebut. Pembelajaran kontekstual melibatkan tujuh komponen utama pembelajaran. Berikut ini adalah uraian mengenai ketujuh komponen utama dalam pembelajaran kontekstual yang terdapat pada Strategi Pembelajaran Berorientasi Standar Proses Pendidikan (Sanjaya, 2006) sebagai berikut:

1. Konstruktivisme, adalah proses membangun atau menyusun pengetahuan baru dalam struktur kognitif siswa bardasarkan pengalaman.

2. Inkuiri, artinya, proses pembelajaran didasarkan pada pencarian dan penemuan melalui proses berpikir secara sistematis. Pengetahuan bukanlah sejumlah fakta hasil dari mengingat, akan tetapi hasil dari proses menemukan sendiri. Dalam hal ini guru yang harus selalu merancang pembelajaran yang memungkinkan siswa dapat menemukan sendiri materi yang harus dipahaminya.

3. Bertanya (Questioning), belajar pada hakikatnya adalah bertanya dan menjawab pertanyaan. Bertanya dapat dipandang sebagai refleksi dari keingintahuan setiap individu; sedangkan menjawab pertanyaan mencerminkan kemampuan seseorang dalam berpikir. Dalam proses pembelajaran melalui CTL, peran bertanya sangat penting, sebab melalui pertanyaan-pertanyaan guru dapat membimbing dan mengarahkan siswa untuk menemukan setiap materi yang dipelajarinya. 
4. Masyarakat Belajar (Learning Community), konsep masyarakat belajar dalam CTL menyarankan agar hasil pembelajaran diperoleh melalui kerjasama dengan orang lain. Kerjasama itu dapat dilakukan dalam berbagai bentuk baik dalam kelompok belajar secara formal maupun dalam lingkungan yang terjadi secara alamiah.

5. Pemodelan (Modeling), adalah proses pembelajaran dengan memperagakan sesuatu sebagai contoh yang dapat ditiru oleh setiap siswa. Misalnya contoh penyelesaian soal, penggunaan alat peraga atau dalam membuat skema konsep.

6. Refleksi (Reflection), adalah proses pengendapan pengalaman yang telah dipelajari yang dilakukan dengan cara mengurutkan kembali kejadian-kejadian atau peristiwa pembelajaran yang telah dilaluinya. Melalui proses refleksi, pengalaman belajar itu akan dimasukkan dalam struktur kognitif siswa yang pada akhirnya akan menjadi bagian dari pengetahuan yang dimilikinya.

7. Penilaian Nyata (Authentic Assessment), dalam CTL, keberhasilan pembelajaran tidak hanya ditentukan oleh perkembangan kemampuan intelektual saja, akan tetapi perkembangan seluruh aspek. Oleh sebab itu, penilaian keberhasilan tidak hanya ditentukan oleh aspek belajar seperti hasil tes, akan tetapi juga proses belajar melalui penilaian nyata.

\section{Kemampuan Koneksi Matematis}

Kemampuan Koneksi Matematis merupakan kemampuan mendasar yang harus dimiliki oleh Siswa sekolah dasar. Pentingnya kemampuan koneksi matematika terkandung dalam tujuan pembelajaran matematika sekolah dasar (KTSP,2006) yaitu Memahami konsep matematika, menjelaskan keterkaitan antar konsep dan mengaplikasikan konsep atau algoritma, secara luwes, akurat, efisien, dan tepat, dalam pemecahan masalah.

Indikator kemampuan koneksi matematik yang digunakan yaitu menurut NCTM (Wahyudin, 2010) ditingkat kelas $\mathrm{K}-4$, studi matematika untuk koneksi sehingga siswa mampu:

- Menghubungkan pengetahuan konseptual dengan pengetahuan prosedural (Link conceptual and procedural knowledge);

- Menghubungkan berbagai representasi konsep atau prosedur satu sama lain (Relate various representations of condepts or prosecedures to one another);

- Mengenali hubungan antara topiktopik berbeda dalam matematika (Recognize relationships among different topics in mathematics);

- Menggunakan matematika dalam area-area kurikulum lainnya (use mathematics in other curriculum areas);

- Menggunakan matematika dalam kehidupan sehari-hari (Use mathematics in their daily lives).

\section{METODE PENELITIAN}

Subyek dalam penelitian ini adalah salah satu kelas dari kelas VIIIC SMP Negeri 1 Maleber tahun pelajaran 2015/2016. Pengambilan subyek dalam penelitian ini adalah kelas VIII C sebanyak 30 siswa dengan pertimbangan bahwa dalam kelas tersebut belum mencapai ketuntasan belajar dan aktivitas siswa dalam pembelajaran masih rendah bila dibandingkan dengan kelas VIII lainnya. Adapun pelaksanaan 
penelitian tindakan kelas ini adalah dimulai dari bulan Oktober 2015 sampai dengan bulan Desember 2015.

Penelitian tindakan kelas dilaksanakan dengan beberapa tingkatan fase yang terdapat dalam tiap siklus. Fase-fase tersebut adalah sebagai berikut :

a) Perencanaan

Tahap perencanaan merupakan tahap di mana disusun langkahlangkah yang hendak dilakukan dalam penelitian. Langkah-langkah tersebut disusun relevan dengan kebutuhan penelitian, seperti membuat rencana program pengajaran yang meliputi bahan ajar, instrumen pengumpul data (lembar observasi, wawancara, studi dokumentasi dan tes) serta menyiapkan hal-hal lain yang mendukung kelancaran pelaksanaan penelitian yang hendak dilakukan.

b) Tindakan

Pada tahap ini peneliti mengkaji lebih lanjut tentang berbagai rencana penelitian yang telah telah disusun sebelumnya, untuk kemudian melaksanakan tindakan penelitian dalam hal ini pelaksanaan pembelajaran dengan menerapkan Pendekatan Contectual dengan mengikuti prinsip kerja penelitian tindakan kelas.

c) Observasi (Pengamatan)

Penelitian tindakan kelas, observasi atau pengamatan terhadap segala aktivitas subyek penelitian dilaksanakan ketika proses pembelajaran itu berlangsung. Observasi ini dilakukan oleh dua orang pengamat dengan berpedoman pada lembar observasi yang telah dipersiapkan sebelumnya. d) Refleksi

Penelitan tindakan kelas setiap pelaksanaan tindakan telah usai pada setiap siklusnya maka dilakukanlah refleksi terhadap halhal yang telah terjadi pada pelaksanaan penelitian sebelumnya. Hal ini bertujuan untuk mengkaji letak kesalahan dan kelemahan tindakan sebelumnya guna melakukan perbaikan pada siklus berikutnya.

Data yang diperoleh dalam penelitian ini melalui lembar observasi untuk mengobservasi siswa yang dilakukan pada proses pembelajaran yang digunakan untuk mencari data suasana belajar dan mengetahui aktivitas belajar siswa. Angket diberikan kepada siswa untuk mendapatkan sejumlah data mengenai tanggapan siswa terhadap penggunaan model pembelajaran Contextual setelah akhir pembelajaran. berupa soal-soal tentang kendala pada dirinya sendiri sehingga diketahui kesulitankesulitan siswa pada mata pelajaran matematika. Serta tes dalam penelitian terdiri dari tes formatif untuk mengetahui tingkat penguasaan kemampuan pemecahan masalah siswa terhadap materi yang disajikan pada proses pembelajaran. Proses analisis data berlangsung dari awal sampai akhir pelaksanaan program tindakan. Data dalam penelitian diolah dan dianalisis dengan mengikuti pola mulai dari tahap observasi sampai tahap berakhirnya seluruh program tindakan.

Pengumpulan data dimaksudkan untuk memadukan semua data hasil penelitian, yakni observasi terhadap siswa dan guru, serta hasil tes. Lembar pengamatan terhadap aktivitas siswa diukur dengan menggunakan beberapa 
aspek dengan dilengkapi kriteria (terlampir), dan masing-masing aspek akan dikategorikan sebagai berikut:

$$
\begin{array}{ll}
0,0-1,0 & \text { tidak baik } \\
1,1-2,0 & \text { kurang baik } \\
2,1-3,0 & \text { cukup baik } \\
3,1-4,0 & \text { baik }
\end{array}
$$

Sedangkan hasil belajar siswa dianalisis sesuai dengan Kriteria Ketuntasan Minimal Mata Pelajaran, yakni siswa dianggap tuntas jika hasil belajar mencapai $\geq 74 \%$.

Untuk itu digunakan rumus ketuntasan belajar sebagai berikut.

a. Ketuntasan belajar tiap siswa $=$

Skor Aktual Siswa

Skor Maksimum Ideal

b.Ketuntasan belajar klasikal = Jumlah Siswa yang Tuntas x 100\% Jumlah Siswa.

\section{HASIL DAN PEMBAHASAN}

Hasil penelitian siklus I diawali dengan perolehan aktifitas siswa termasuk kategori kurang baik, pada siklus II kategori cukup baik, ini berarti ada peningkatan aktivitas dari siklus 1 ke siklus 2. Hasil observasi aktivitas siswa pada siklus III termasuk kategori baik, jadi hampir semua siswa menilai positif dengan adanya penelitian ini.

Hasil penelitian kemampuan koneksi melalui hasil ulangan siklus I, hasil belajar siswa belum maksimal sesuai dengan pembelajaran pendekatan contextual. pada nilai hasil belajar siswa diperoleh ketuntasan klasikal di bawah Kriteria ketuntasan Minimum $(\mathrm{KKM}=74)$, siswa yang berhasil mendapat KKM ada 12 siswa dari 30 siswa, ini berarti diperoleh ketuntasan klasikal sebesar $40 \%$, dengan rata rata kelas 68 Jadi hasil belajar siswa pada siklus I dikatakan belum tuntas. Kemungkinan ketidakberhasilan pada siklus I ini dikarenakan mereka masih sulit menangkap pembelajaran pendekatan Contextual.

Pada siklus II. nilai hasil belajar siswa diperoleh ketuntasan klasikal sebesar $60 \%$, Sedangkan rata rata kelas hanya mencapai 74 , siswa yang berhasil hanya 18 siswa. Ini berarti ada peningkatan . Kemajuan dari siklus II terhadap siklus I ini dikarenakan mereka, baik guru maupun siswa sudah mulai memahami makna dengan pendekatan Contextual untuk meningkatkan kemampuan koneksi pada materi pembelajaran SPLDV dengan metode eliminasi. Namun untuk memperoleh hasil yang lebih maksimal lagi dari pembelajaran dengan pendekatan contextual untuk meningkatkan kemampuan koneksi pada materi pembelajaran SPLDV ini, maka peneliti melakuan usaha perbaikan pada siklus III. Hasil penelitian pada siklus III ketuntasan klasikal sesuai kriteria ketuntasan minimal, yakni 76,67\%. Dan rata rata kelas 78 berada di atas KKM Artinya, siswa sudah mulai memahami makna dengan pendekatan contextual untuk meningkatkan kemampuan koneksi pada materi pembelajaran SPLDV.

Hasil penelitan pada angket respon siswa didapat sebagian besar siswa menunjukan respon yang sangat kuat jika dilihat dirata rata yaitu 85,5 $\%$ dapat diartikan bahwa penggunaan Pembelajaran pendekatan kontektual mudah dipahami. Ini berarti hampir semua siswa merespon positif terhadap penerapan pendekatan Contextual dalam meningkatkan kemampuan koneksi matematis siswa pada materi SPDLV seperti terlihat pada Tabel 1, Tabel 2, Grafik 1 dan Grafik 2. 
Tabel 1.

Rekapitulasi Aktifitas Siswa

\begin{tabular}{|c|c|}
\hline Siklus & Rata Rata Hasil Aktifitas Siswa \\
\hline Siklus I & 1,5 \\
\hline Siklus II & 2,4 \\
\hline Siklus III & 3,6 \\
\hline
\end{tabular}

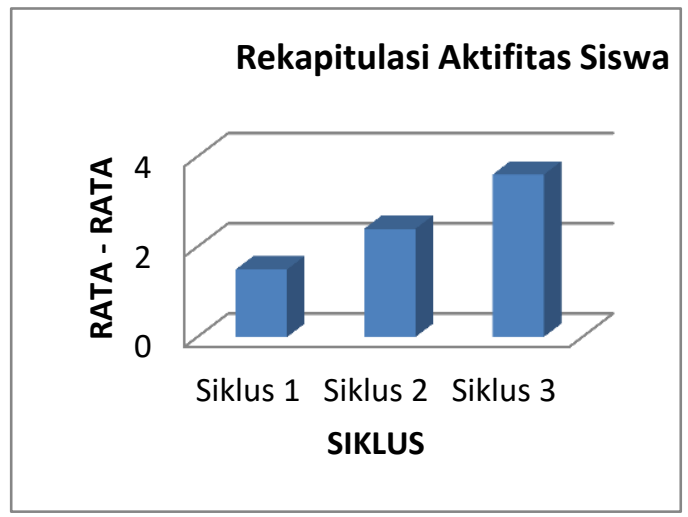

Grafik 1.

Rekapitulasi Aktifitas Siswa

Tabel 2.

Rekapitulasi Kemampuan Koneksi Siswa

\begin{tabular}{|c|c|}
\hline Siklus & $\begin{array}{c}\text { Rata Rata Kemampuan } \\
\text { Koneksi }\end{array}$ \\
\hline Siklus I & 68 \\
\hline Siklus II & 74 \\
\hline Siklus III & 79 \\
\hline
\end{tabular}

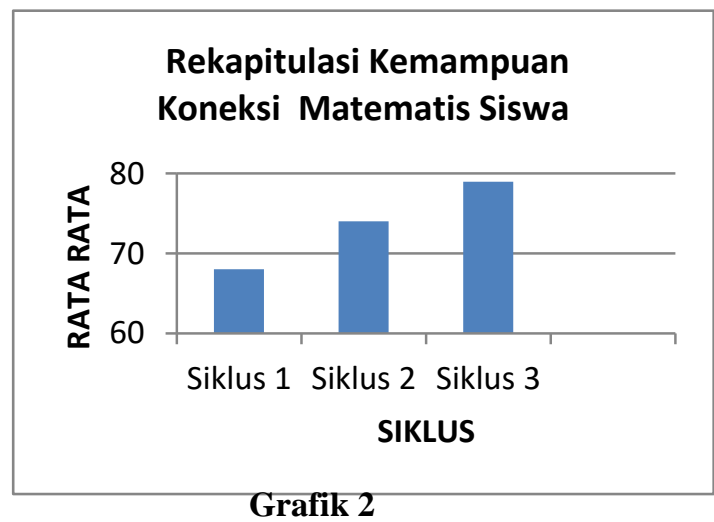

Rekapitulasi Kemampuan Koneksi Siswa

Guru harus pandai membawa siswanya kepada tujuan yang hendak dicapai, oleh sebab itu Keberhasilan belajar dalam kemampuan koneksi matematis siswa lebih banyak ditentukan oleh guru dalam mengelola kelas, Pada hakekatnya guru terus berupaya untuk dapat memberikan yang terbaik bagi siswanya, dengan memperbaiki berupaya memberikan pegetahuan dan pengalaman kontektial yang diiharapkan menjadi pembelajaran yang bermakna bagi siswa. Dengan demikian aktifitas siswa mempengaruhi kemampuan koneksi matematis siswa.

Berdasarkan data-data yang telah diuraikan di atas, diperoleh keterangan bahwa indikator keberhasilan tindakan yang ditetapkan telah tercapai, yaitu tingkat keberhasilan aktifitas siswa dan kemampuan koneksi matematis siswa melalui hasil belajar mengalami peningkatan setiap siklusnya. Dengan demikian Penelitian pada siswa kelas 8C SMP Negeri I maleber Tahun Pelajaran 2015/2016 ini selesai.

\section{KESIMPULAN DAN SARAN Kesimpulan}

1. Aktivitas siswa kelas 8C SMP Negeri 1 Maleber terhadap pembelajaran dengan Pendekatan contextual Pada Materi Sistem Persamaan linear Dua variabel dapat meningkatkan kemampuan koneksi Siswa ini terlihat pada peningkatan hasil belajar pada setiap siklusnya siklus I diawali dengan perolehan aktifitas siswa termasuk kategori kurang baik, pada siklus II kategori cukup baik, pada siklus III termasuk kategori baik, jadi hampir semua siswa menilai positif dengan adanya penelitian ini.

2. Pembelajaran dengan Pendekatan contextual Pada Materi Sistem Persamaan linear Dua variabel dapat meningkatkan kemampuan koneksi Siswa terlihat dengan adanya peningkatan dari diperoleh ketuntasan klasikal sebesar $40 \%$, dengan rata rata kelas 68 pada 
siklus 1 , dan pada siklus II diperoleh ketuntasan klasikal sebesar $60 \%$, Sedangkan rata rata kelas hanya mencapai 74 , pada siklus III ketuntasan klasikal sesuai kriteria ketuntasan minimal, yakni $76,67 \%$. Dan rata rata kelas 78 berada di atas KKM. Artinya, siswa sudah mulai memahami makna dengan pendekatan contextual untuk meningkatkan kemampuan koneksi pada materi pembelajaran SPLDV.

3. Hasil penelitan pada angket respon siswa didapat sebagian besar siswa menunjukan respon yang sangat kuat jika dilihat dirata rata yaitu $85,5 \%$ dapat diartikan bahwa penggunaan Pembelajaran pendekatan contextual mudah dipahami. Ini berarti hampir semua siswa merespon positif terhadap penerapan pendekatan contextual dalam meningkatkan kemampuan koneksi matematis siswa pada materi SPDLV.

\section{Saran}

1. Berikan motifasi kepada anak bahwa mempelajari matematika tidak sesulit yang mereka bayangkan.

2. Dalam pembelajaran diusahakan materi pembelajaran diarahkan dengan kehidupan nyata di lapangan, atau lingkungan,sehingga walaupun materi matematika abstrak tapi mereka mampu memanipulasi dari kongkrit ke abstrak.

3. Ciptakan situasi pembelajaran yang aktif, kreatif dan menyenangkan bagi anak ,jangan sebaliknya guru matematika belum masuk siswa sudah stress duluan karena gurunya galak dan alasan lainnya.

\section{DAFTAR PUSTAKA}

Johnson, E.B. (2010). Contextual Teaching \& Learning. Bandung: MLC.

KTSP. (2016). Kurikulum Tingkat Satuan Pendidikan. Jakarta: KEMDIKBUD.

Sanjaya, W. (2014). Startegi Pembelajaran Berorientasi Standar Proses Pendidikan. Jakarta: Kencana Prenada Media Group.

Sumarmo, U. (2012). Bahan Ajar Matakuliah Proses Berpikir Matematik Program S2 Pendidikan Matematika STKIP Siliwangi 2012. Bandung: diterbitkan.

Wahyudin. (2010). Materi Pelajaran Matematika Kelas Rendah. Bandung: Mandiri Bandung. 
CProgram Studi Pendidikan Matematika 